\title{
CINISMO POLÍTICO. UN NUEVO ESTILO DISCURSIVO EN LAS DEMOCRACIAS LIBERALES
}

\section{POLITICAL CYNICISM. A NEW DISCURSIVE STYLE IN LIBERAL DEMOCRACIES}

\section{José Luis López de Lizaga}

Universidad de Zaragoza, España

lizaga@unizar.es

Resumen: Este artículo parte de la hipótesis de que en las democracias liberales actuales se extiende un nuevo estilo discursivo propiamente cínico. El artículo traza una genealogía de este cinismo político partiendo del liberalismo político de John Rawls y recalando en la teoría agonística de la democracia de Chantal Mouffe, e intenta mostrar que la superación del liberalismo político que la teoría agonística lleva años proponiendo parece realizarse finalmente a través del cinismo, aunque con resultados diferentes de los esperados: la expansión del cinismo en la esfera pública debe entenderse como una degradación del debate público con consecuencias políticas inquietantes.

Abstract: A new properly cynical discursive style is spreading in current liberal democracies. This paper traces a genealogy of this political cynicism starting from the political liberalism of John Rawls and making a stopover in Chantal Mouffe's agonistic theory of democracy, and tries to show that the overcoming of the political liberalism that the agonistic theory has been proposing for years seems to be finally carried out through cynicism, although with different results than expected: the expansion of cynicism in the public sphere must be understood as a degradation of public debate with disturbing political consequences.

\section{l. Introducción}

Cuando tratamos de analizar fenómenos políticos que parecen novedosos, corremos el riesgo de precipitarnos e identificar grandes cambios históricos que los hechos desmienten al cabo de pocos meses o años. Y este riesgo, al que estamos expuestos

1. Este artículo se ha elaborado en el marco del Proyecto I+D «Racionalidad económica, ecología política y globalización: hacia una nueva racionalidad cosmopolita» (PID2019-109252RB-I00). 
siempre, parece agudizarse hoy, un tiempo de transformaciones aceleradas, gran confusión y diagnósticos volátiles. Pese a ello, en estas páginas voy a aventurarme a hablar de algo que me parece nuevo e importante: se trata de lo que llamaremos cinismo político, un fenómeno más bien borroso que aquí interpretaremos como un estilo discursivo que empieza a afianzarse en el debate público de las democracias liberales. El cinismo político consiste esencialmente en defender en la esfera pública posiciones políticas sin ningún fundamento, o en sostener afirmaciones manifiestamente falsas o inaceptables. ${ }^{2}$ En estas páginas propondremos una genealogía de este nuevo estilo partiendo del liberalismo político de John Rawls y recalando en la teoría agonística de la democracia de Chantal Mouffe. Intentaremos mostrar que el cinismo socava el liberalismo político de un modo mucho más radical que la teoría agonística, la cual, a pesar de su voluntad de ruptura con el liberalismo, debe interpretarse más bien como una variante de éste. La superación del liberalismo político que la teoría agonística lleva años proponiendo parece realizarse finalmente a través del cinismo, aunque con resultados diferentes de los esperados. Una vez trazada esta genealogía, y dado que ni los liberales ni los agonísticos han dicho hasta ahora casi nada sobre el cinismo político, buscaremos en los escritos de Peter Sloterdijk un punto de apoyo para analizar este fenómeno. La tesis principal que sostendremos en estas páginas puede resumirse, pues, de este modo: la expansión del cinismo en la esfera pública implica un cuestionamiento del

2. El cinismo político es, pues, la extensión a la esfera pública de actitudes que el diccionario de la RAE define muy acertadamente como "desvergüenza en el mentir o en la defensa de acciones o doctrinas vituperables." liberalismo político mucho más serio que el planteado por las teorías agonísticas, y debe entenderse como una degradación del debate público con consecuencias inquietantes, puesto que el cinismo suele aliarse con actitudes fascistas.

\section{Liberalismo político}

En el tránsito de la sociedad del Antiguo Régimen a la sociedad moderna, la defensa de la libertad de opinión y de expresión no fue solo un arma favorable a los intereses políticos y económicos de la burguesía en ascenso, sino que también tenía una justificación epistémica. La llustración concibió la libre confrontación de ideas en la esfera pública como un medio para alcanzar cooperativamente la verdad acerca del mundo y la justicia en los conflictos de intereses, puesto que solo el intercambio de argumentos sin censuras permite cribar las opiniones fundadas de las que no lo están, y solo la defensa de todos los intereses sin exclusiones permite alcanzar acuerdos aceptables por todas las partes en conflicto. ${ }^{3}$ Esta confianza en el poder de los argumentos no era ingenua, y no en vano el moderado reformismo de muchos ilustrados dio paso a posiciones netamente revolucionarias tan pronto como quedó de manifiesto que, en las luchas políticas del siglo XVIII, la parte contraria -es decir, los partidarios del Antiguo Régimen- no estaba dispuesta a atender a razones, y que por tanto

3. Jürgen Habermas analizó en profundidad la relación entre la emergencia de una esfera pública política y el tránsito del Antiguo Régimen a la sociedad moderna en Strukturwandel der Öffentlichkeit (1962). Desde una perspectiva ideológica diferente, Reinhart Koselleck había estudiado el mismo proceso en Kritik und Krise (1959). 
el triunfo de la verdad o la realización de la justicia necesitarían recurrir a medios menos pacíficos y menos elegantes que eso que Jürgen Habermas ha llamado muchas veces la "coacción sin coacciones del mejor argumento." ${ }^{4}$ Pero para el liberalismo político heredero de la llustración, la violencia revolucionaria es un mal que las circunstancias a veces hacen necesario, pero que no desmiente las bondades de la deliberación racional. Ésta sigue siendo la mejor forma de dirimir las diferencias de opinión y los conflictos de intereses, y debe prevalecer siempre que las condiciones sociales lo permitan. Por eso la libertad de expresión y el libre intercambio de argumentos tuvo importantes valedores también después de la Revolución. Como señala Carl Schmitt, el liberalismo y el parlamentarismo de los siglos XIX y XX se asentó en esta confianza en la discusión libre en los parlamentos, la prensa y la esfera pública como medio

4. Si la Ilustración y la Revolución estuvieron tan próximas histórica y conceptualmente, ello se debe a que el poder de las razones no siempre es suficiente, y a que a menudo -por decirlo con Marx- "el arma de la crítica" resulta ineficaz sin la complementaria "crítica de las armas". Dos figuras de la Ilustración alemana muy representativas de esta proximidad entre racionalismo y revolución son Kant y Georg Forster. El primero no logró nunca resolver plenamente la tensión entre su reformismo ilustrado (expuesto, por ejemplo, en el famoso ensayo "¿Qué es la Ilustración?”, de 1784) y su compromiso con la Revolución francesa. El segundo transitó de una primera posición reformista y racionalista a una segunda posición completamente revolucionaria. Cf. sobre esto López de Lizaga, J. L. (2012). “¿Razón o revolución? El republicanismo de Kant y Georg Forster”, Foro Interno, vol. 12, 81-106, y López de Lizaga, J. L. (2019). "El entusiasmo de la Revolución. Sobre la filiación kantiana del último Foucault", Ágora, Vol. 38, n 1, 165-181. para "engendrar una legislación y una política verdaderas y correctas". 5

Pero ¿significa esto que para la llustración y el liberalismo es inconcebible el disenso, o que toda deliberación en la que las partes argumentan de buena fe -es decir: con el objetivo de establecer en común la opinión más verdadera o la interacción más justa- debe concluir indefectiblemente en una, y solo una, posición compartida por todos? Es frecuente interpretar de este modo la concepción de la deliberación que caracteriza al liberalismo político o a la teoría de la democracia deliberativa, ${ }^{6}$ pero esta interpretación se ve desmentida por la extensa teoría del disenso político que ha desarrollado un autor liberal tan destacado como John Rawls. De hecho, la cuestión del disenso es el tema principal de El liberalismo político (1993), obra en la que Rawls -como él mismo señala en la Introducción- se proponía revisar un supuesto implícito de su Teoría de la justicia (1971), a saber: el supuesto de que todos los ciudadanos de una democracia liberal compartirán una misma concepción del mundo, una misma orientación ética y unos mismos valores fundamentales. $^{7}$ En su libro de 1993, Rawls revisa este supuesto para dar cuenta del fenómeno del "pluralismo razonable", es decir: del hecho de que en las sociedades democráticas conviven concepciones del mundo y orientaciones éticas -o "doctrinas comprehensivas", por decirlo en la terminología rawlsiana- totalmente distintas, y a menudo incompatibles. Es verdad

5. Schmitt, C. (2002/1923). Sobre el parlamentarismo, Madrid, Tecnos, p. 65.

6. Así, por ejemplo, Ch. Mouffe, siguiendo a Schmitt también en esto. Volveremos sobre ello en este artículo.

7. Rawls, J. (2003/1993). El liberalismo politico, Barcelona, Crítica, pp. 11-13. 
que a Rawls le interesa sobre todo investigar cómo puede establecerse una base común para la controversia política entre doctrinas comprehensivas diferentes; y es verdad, por tanto, que su teoría se orienta más a analizar las condiciones del consenso que a celebrar o promover el disenso (que es lo que harán, como veremos más adelante, los partidarios de una teoría agonística de la democracia). Pero no menos cierto es que el liberalismo político rawlsiano, lejos de ignorar o minimizar el desacuerdo que caracteriza a las sociedades democráticas, más bien lo toma como punto de partida. Ahora bien, ¿qué clase de disenso es este que caracteriza a estas sociedades?

Comencemos por aclarar por qué difieren, según Rawls, nuestras doctrinas comprehensivas, y sobre todo: por qué el disenso persiste aunque intentemos ponernos de acuerdo en torno a ellas. Esto, señala Rawls, es una característica que distingue a las doctrinas comprehensivas de las teorías científicas, o al menos de aquellas teorías pertenecientes a las ciencias más serias o más duras, que se reconocen precisamente porque tienden a superar el disenso. ${ }^{8}$ Las controversias científicas se dirimen (no siempre inmediatamente, pero sí a largo plazo) mediante el logro de un consenso en torno a la teoría provisionalmente mejor fundada, mientras que las controversias morales, sociales y políticas no siempre se resuelven ni conducen a consensos, por mucho que prolonguemos la deliberación. Podría pensarse que esta persistencia del disenso se debe, en general, a una carencia generalizada de racionalidad, pero Rawls rechaza expresa-

8. Ibíd. p. 85: “¿Por qué el intento consciente de razonar unos con otros no habría de conducir a un acuerdo razonable? Esto es lo que ocurre en las ciencias naturales, al menos a largo plazo." mente esta explicación. Nadie negará que nuestros puntos de vista a veces difieren porque reflejan "estrechos intereses" o porque la gente es -como dice Rawls sin hacer demasiadas concesiones a la political correctness- "por lo común irracional y no demasiado lista". ${ }^{9}$ Pero estas fuentes irracionales de desacuerdo no son las únicas, ni las más importantes: "Es irrealista -0, peor aún, provoca suspicacia y hostilidad mutuas- el supuesto de que todas nuestras diferencias están arraigadas en la ignorancia y la perversión, si no en rivalidades de poder, estatus o ventaja económica."10 Rawls propone, pues, una explicación diferente de la persistencia del disenso ético y político. Las diferencias de criterio en sociedades complejas y culturalmente heterogéneas no son irracionales (es decir: no son consecuencia de la ignorancia, la mala voluntad o la falta de inteligencia de alguna o de todas las partes en conflicto), sino que se derivan del simple hecho de que el libre ejercicio de nuestra capacidad de razonar conduce muchas veces a resultados diferentes. Precisamente por eso son también diferencias ineliminables.

Rawls acuña el tecnicismo de "cargas del juicio" para referirse a las fuentes no irracionales de desacuerdo, y en El liberalismo político menciona algunas de ellas, aunque sin pretender analizarlas exhaustivamente. ${ }^{11}$ Diferimos, en primer lugar, (1) por las dudas que quedan casi siempre tras examinar las evidencias disponibles sobre cualquier cuestión controvertida. E incluso cuando disponemos de datos indudables, diferimos (2) acerca de la relevancia que concedemos a unos o a

9. Ibíd., p. 86 .

10. Ibíd., p. 89.

11. Ibíd., p. 85 y sigs. 
otros. Diferimos también (3) por la vaguedad y los "límites imprecisos" de nuestros conceptos "morales y políticos"12. Pero sobre todo, diferimos (4) porque escogemos orientaciones éticas y políticas articuladas en torno a valores y cosmovisiones diversos. Aunque Rawls no se detiene a analizar casos concretos, no es difícil imaginar ejemplos de controversias actuales que se originan precisamente en estas cargas del juicio que hemos mencionado. ¿Aumentan o no los casos controvertidos de eutanasia allí donde se despenaliza esta práctica? ¿Importa o no el momento exacto en que el embrión desarrolla un sistema nervioso para saber hasta cuándo es lícita la manipulación de embriones? ¿La libertad política consiste sobre todo en la libertad negativa frente al Estado, o más bien en la libertad positiva del ciudadano que participa democráticamente en el Estado? ¿Preferimos la libertad de mercado o la justicia social? ¿Preferimos una ética de la autonomía individual o una ética que subordina la individualidad a la tradición, la religión o la comunidad? Etc., etc.

Lo más cómodo sería que estas controversias no existieran y que nuestras democracias se asentaran en una compacta homogeneidad cultural; o que, en caso de existir, pudieran despejarse fácilmente acallando a la parte contraria mediante alguna prueba contundente de su ignorancia o de su mala voluntad. Pero nada de eso es posible casi nunca, y más bien tenemos que aceptar la convivencia en condiciones de desacuerdo ineliminable. Rawls resume el asunto de este modo: las "cargas del juicio" (esto es, las fuentes no irracionales de disenso político) tienen como consecuencia que la mayor parte de nuestras controversias no conduzcan a soluciones unánimes "ni siquiera des-

12. Ibíd. p. 87. pués de una discusión libre". ${ }^{13}$ Y dado que el pluralismo ideológico de las sociedades democráticas no solo es inevitable, sino que además es razonable y totalmente legítimo, la pregunta a la que pretende dar respuesta la teoría política rawlsiana es la siguiente: cómo es posible (y eventualmente cómo podemos hacer posible) la estabilidad de las sociedades democráticas en las que coexisten doctrinas éticas y políticas heterogéneas, incluso enfrentadas. Rawls lo plantea en estos términos:

El problema del liberalismo político es: ¿cómo es posible que pueda persistir en el tiempo una sociedad estable y justa de ciudadanos libres e iguales que andan divididos por doctrinas religiosas, filosóficas y morales razonables pero incompatibles? Dicho de otro modo: ¿cómo es posible que doctrinas comprehensivas profundamente enfrentadas, pero razonables, puedan convivir y abrazar de consuno la concepción política de un régimen constitucional? ¿Cuál es la estructura y cuál el contenido de una concepción política que pueda atraerse el concurso de un consenso entrecruzado de este tipo? ${ }^{14}$

La respuesta que Rawls propone para estas preguntas está centrada en su conocido concepto de razón pública, es decir: en la identificación de un conjunto de principios políticos que deben compartir todos los ciudadanos, sean cuales sean sus respectivas doctrinas comprehensivas, y en cuyos términos deben articular sus posiciones "cuando se comprometan en defensa de una determinada política en el foro público." ${ }^{15}$ El contenido de la razón pública puede especificarse de

13. Ibíd., p. 89.

14. Ibíd., pp. 13-14.

15. Ibíd., p. 250. 
distintas formas, ${ }^{16}$ y por eso los textos de Rawls son bastante imprecisos cuando se trata de concretar esos principios. Pero como mínimo, parece claro que una argumentación política basada en la razón pública de una democracia liberal debe (1) reconocer la libertad y la igualdad de todos los ciudadanos (incluidos todos aquellos que no comparten nuestras doctrinas comprehensivas), y debe (2) basarse en el supuesto de que la sociedad es un "esquema equitativo de cooperación", es decir: un orden en el que la interacción debe considerarse legítima por todos los participantes, y no simplemente un orden fijado autoritariamente, por ejemplo "mediante valores religiosos o aristocráticos".${ }^{17} \mathrm{~A}$ esto podemos añadir -y Rawls también lo hace-que la razón pública de las democracias liberales incluye (3) los principios normativos recogidos en la Declaración de los Derechos Humanos de 1948 y plasmados luego en las Constituciones democráticas. ${ }^{18}$ Así, y volviendo a nuestros ejemplos anteriores:

16. Rawls, J. (2001/1999). "Una revisión de la idea de razón pública”, en El derecho de gentes, Barcelona, Paidós, p. 167.

17. Rawls, J. El liberalismo político, op. cit., p. 45. Cf. también J. Rawls, "Una revisión de la idea de razón pública”, op. cit., p. 165ss.

18. Rawls, J. El liberalismo político, op. cit., p. 252: "nuestro ejercicio del poder político es propia y consiguientemente justificable solo si se realiza de acuerdo con una constitución, la aceptación de cuyas esencias puede razonablemente presumirse de todos los ciudadanos." Naturalmente, para poder ser compartidos y aceptados por todos (aunque sea por razones diferentes), los principios de la razón pública deben ser considerados por todos como independientes de cualquier doctrina comprehensiva, y es a esto a lo que Rawls se refiere cuando dice que los principios que regulan la convivencia en las democracias liberales han de ser "políticos, pero no metafísicos" (op. cit., p. 40, cf. también p. 186 ss). opinemos lo que opinemos sobre cuestiones controvertidas como la eutanasia, la investigación con embriones, la relación de la libertad de mercado con la justicia social, o el valor de la autonomía individual frente a la autoridad de la tradición o la religión, en tanto que ciudadanos de una sociedad democrática culturalmente fragmentada y heterogénea solo tenemos derecho a defender nuestras posiciones en relación con cualquiera de estos asuntos reconociendo a otros la libertad de pensar de manera distinta de la nuestra, argumentando frente a ellos nuestros puntos de vista, y empleando para ello únicamente el entramado de principios políticos compartidos por todos que constituyen la razón pública de la sociedad a la que pertenecemos. ${ }^{19}$

Todo lo anterior tiene una importante consecuencia para nuestro tema: nos permite comprender dónde termina el desacuerdo "razonable" e identificar al principal antagonista del liberalismo político. En su estilo a veces descuidado y sorprendentemente impreciso, Rawls habla constantemente de "pluralismo razonable" y de "doctrinas comprehensivas razonables", 20 pero si leemos con atención observaremos que en la teoría rawlsiana lo razonable (o irrazonable) no son tanto las doctrinas cuanto las personas que las profesan y las defienden públicamente, es decir: los ciudadanos. Y esta matización (que el

19. Esto implica que, por ejemplo, los argumentos pertenecientes a doctrinas comprehensivas religiosas deben quedar excluidos de las deliberaciones públicas. Para una comparación de este asunto en Rawls y Habermas, cf. López de Lizaga, J. L. (2011). "Verdades religiosas, política laica: Habermas sobre la religión en la esfera pública", en J. Franzé y J. Abellán (eds.), Política $y$ Verdad, Madrid, Plaza y Valdés, pp. 175-208.

20. Cf. por ejemplo Rawls, J. El liberalismo politico, op. cit., p. 12 ; p. 89 y sigs. 
propio Rawls descuida) es importante. ${ }^{21}$ Irrazonables no son las doctrinas, sino sus partidarios, cuando no mantienen hacia sus propias convicciones la elemental prudencia falibilista que se precisa para aceptar que existen otros puntos de vista además de los suyos y otros argumentos que quizás no conocen o no comparten, pero que no por eso pueden considerar rotundamente falsos. Irrazonables son, por encima de todo, quienes se muestran dispuestos a imponer a otros su propia doctrina comprehensiva, sea ésta cual sea, simplemente porque están convencidos de que es la única doctrina verdadera. Vale la pena citar con alguna extensión lo que Rawls escribe sobre esto:

Puesto que hay muchas doctrinas que se consideran razonables, quienes insisten, a

21. En el capítulo segundo de El liberalismo político leemos que las doctrinas razonables se caracterizan por estos rasgos: tienen un componente teórico ("expresan una concepción inteligible del mundo") y un componente práctico ("proporcionan criterios" para dirimir conflictos entre valores), y además pertenecen siempre a alguna "tradición intelectual o doctrinal" (op. cit., p. 90). Pero es obvio que estos rasgos pueden constatarse en cualquier doctrina comprehensiva, de manera que no sirven como criterio de demarcación entre las que son razonables y las que no lo son. Por eso parece más correcto afirmar que lo que cualifica como "razonable" a una doctrina, y por tanto como apta para circular libremente en el espacio público de las sociedades democráticas, es más bien la actitud de sus partidarios, especialmente en sus relaciones con los partidarios de doctrinas rivales. Por otra parte, la irrazonabilidad de las actitudes es a veces indisociable del contenido de ciertas doctrinas comprehensivas, precisamente aquellas que implican la persecución de la disidencia, o aquellas que niegan a otros su derecho a pensar o a vivir como quieran (o incluso a vivir, sin más) porque, por ejemplo, los consideran naturalmente inferiores. Las doctrinas excluyentes y las actitudes irrazonables suelen aparecer juntas. la hora de enfrentarse a cuestiones políticas fundamentales, en lo que ellos consideran verdadero y los demás no, aparecen a los ojos de los demás como si insistieran en imponer sus propias creencias cuando disponen del poder político para hacerlo. $\mathrm{Ni}$ que decir tiene que quienes insisten en sus creencias insisten también en que solo ellas son verdaderas: imponen sus creencias porque, dicen, sus creencias son verdaderas, no porque sean suyas. Pero se trata de una pretensión que todos podrían tener; es, además, una pretensión que nadie está en condiciones de justificar ante el común de los ciudadanos. Así pues, cuando exponemos tales pretensiones, los demás, que son razonables, tienen que considerarnos como irrazonables. Y en efecto lo somos, si lo que deseamos es usar el poder estatal, el poder dimanante de la colectividad de ciudadanos iguales, para impedir al resto la afirmación de sus no irrazonables concepciones. ${ }^{22}$

Vemos, pues, que para el liberalismo político el irrazonable es sobre todo el dogmático, el fanático, el autoritario, y lo de menos es la doctrina que profese. Irrazonables son quienes imponen sus creencias porque afirman que sus creencias son verdaderas, no porque sean suyas, y quienes por tanto suscribirían la inquietante sentencia del obispo Bossuet que también cita Rawls: "tengo derecho a perseguirle a usted porque yo llevo razón y usted se equivoca."23 Cuando se abre paso este fanatismo, el liberalismo político está acabado. Por eso las democracias liberales, y la teoría de Rawls con ellas, ahuyentan esta amenaza proscribiendo las doctrinas irrazonables, que de todas formas se delatan y excluyen a sí mismas por el hecho de que no pueden articu-

22. Rawls, J. El liberalismo político, op. cit., p. 92. 23. Bossuet, cit. en Rawls, J. El liberalismo politico, op. cit., p. 92, n. 16. 
larse en los términos de la razón pública -puesto que nadie puede invocar un derecho fundamental a negarle a otro sus derechos fundamentales, empezando por el derecho a disentir-, y por ello quedan justamente excluidas del espacio público.

\section{Democracia agonística}

La filosofía política de Rawls es un reflejo de las democracias liberales de las últimas décadas del siglo XX, un contexto que observamos hoy con cierta distancia, y quizás también con nostalgia porque lo recordamos como menos convulso que el nuestro. ${ }^{24}$ En aquellas democracias, los viejos antagonismos de clase -los grandes ausentes, por cierto, de la teoría política rawlsiana en general, y de El liberalismo político en particular- habían quedado relativamente pacificados por las políticas del Estado del bienestar que se implantaron con éxito en las sociedades industriales tras la Segunda Guerra Mundial. ${ }^{25}$ Y una vez sellada en esas sociedades (y en consecuencia, omitida también en la teoría) esa fuente de más antiguas y más violentas fracturas, la política democrática parecía discurrir rutinariamente por los cauces que tan bien refleja el pensamien-

24. Quizás sin razón, puesto que el pensamiento de Rawls se fraguó sobre un trasfondo histórico tan convulso y violento como lo fueron los Estados Unidos de la década de 1960.

25. La ausencia de referencias a conflictos de clase no es exclusiva de Rawls, sino de buena parte de la filosofía política norteamericana. Noam Chomsky tiene una explicación para esto: "Estados Unidos nunca desarrolló un sistema político basado en clases. Es un sistema político geográfico y se remite a los tiempos de la Guerra Civil." Chomsky, N. et al. (2017). Neofascismo: De Trump a la extrema derecha europea, Capital Intelectual. Edición de Kindle, p. 92. to de Rawls: existían intereses diferentes y opuestos, aunque no tanto como para que se quebrara el consenso de fondo en torno al marco común de convivencia; y existían concepciones del mundo y orientaciones éticas heterogéneas y contradictoras, pero todas ellas podían reconocerse mutuamente como razonables y coexistir de un modo relativamente pacífico, a condición de que sus partidarios renunciasen a arrogarse dogmáticamente una injustificada superioridad epistémica y a la consiguiente pretensión de imponer a otros por la fuerza su propia visión del mundo. De acuerdo con este modelo, la política de las democracias liberales pacificadas podía enfocarse como una pugna de intereses enfrentados pero no propiamente antagónicos, y como una confrontación de formas de vida diferentes pero no propiamente excluyentes.

Pero a esta imagen de las democracias modernas pronto se le reprochó cierta miopía para otras formas de conflicto político que, o bien estaban más próximas a la lucha de clases (en su versión clásica o en sus manifestaciones más recientes), o bien no encajaban en el marco del pluralismo de doctrinas comprehensivas razonables. Así, desde la última década del pasado siglo autores como Chantal Mouffe desarrollaron una filosofía política centrada en analizar en la teoría, y en reivindicar en la práctica, esas otras formas de antagonismo que quedan fuera del campo de visión del liberalismo rawlsiano o de otras teorías similares. Esta nueva concepción agonística de la política, contrapuesta a la concepción deliberativa, no ha dejado de cosechar éxitos en lo que llevamos de siglo XXI, probablemente porque capta mejor que el modelo deliberativo el malestar y la indignación que recorren las sociedades democráticas y sus esferas públicas 
desde hace algunos años. ${ }^{26}$ La reivindicación de un modelo agonístico de democracia ha resultado especialmente eficaz cuando se ha dirigido contra el "consenso centrista"27 de conservadores y socialdemócratas que, tras la desaparición de la Unión Soviética, contribuyó a afianzar la hegemonía del neoliberalismo y a tender la trampa de una situación post-democrática en la que parecen haber caído las sociedades actuales, asediadas por poderes económicos incontrolables en un contexto global de creciente desregulación económica. ${ }^{28}$ Por eso el modelo agonístico de democracia aportó también el andamiaje conceptual de la corriente de populismo progresista que irrumpió en la resaca de la crisis financiera de 2008. ${ }^{29}$ No obstante, a pesar de cierta ambigüedad en los escritos de Chantal Mouffe, y a pesar de que esta autora se inspira en un pensador manifiestamente antiliberal como Carl Schmitt, lo cierto es que la teoría agonística de la democracia no propone una ruptura con el marco de la democracia liberal, sino más bien una radicalización o dinamización de ese mismo modelo. Vistas las cosas de este modo, la constante polémica de Mouffe con Rawls (o con Habermas) se parece más a una disputa de familia que a un divorcio, y más de un indicio sugiere que la teoría agonística se limita a ofrecer una descripción alternativa de exactamente los mismos fenómenos

26. Cf. Castells, M. (2020). Ruptura. La crisis de la democracia liberal, Madrid, Alianza.

27. Mouffe, Ch. (2012). La paradoja democráti$c a$, Barcelona, Paidós, p. 24.

28. El término "post-democracia" fue acuñado por Crouch, C. (2004). Posdemocracia, Madrid, Taurus. Ch. Mouffe suele hablar más bien de "post-política."

29. En esta corriente podemos inscribir a autores como Ch. Mouffe, W. Streeck o N. Fraser. que encontramos en los libros de sus rivales, si bien los escritos de Mouffe están dotados, ciertamente, de un pathos más activista y más entretenido que las sesudas disertaciones de los autores liberales.

Justamente esa afinidad de fondo torna crucial para los teóricos agonísticos marcar distancias con la teoría matriz, y Chantal Mouffe recurre para ello a una dudosa estrategia hermenéutica, que consiste en hacer decir a sus rivales liberales lo que no dicen, para después decir ella misma lo que dicen ellos y presentarlo como si fuera una crítica del liberalismo político. Por eso leemos en La paradoja democrática que la teoría de Rawls tiende a "expulsar (...) de la esfera pública cualquier oposición legítima", 30 cuando el tema principal de su liberalismo político es -como hemos visto- precisamente el disenso. 0 leemos que el concepto rawlsiano de una sociedad bien ordenada corresponde a "una sociedad en la que se ha eliminado la política", "la lucha democrática entre adversarios" y "el desacuerdo legítimo". ${ }^{31}$ O que el objetivo del liberalismo político es la "unanimidad y homogeneidad"32 de una sociedad en "perfecta armonía o transparencia"33, y en la que "el pluralismo haya sido superado". ${ }^{34}$ Es verdad que Rawls no se demora tanto como Mouffe en subrayar y ensalzar permanentemente el antagonismo social, pero bajo el aséptico rótulo del "pluralismo razonable" cabe incluir conflictos bastante agudos, como lo son, efectivamente, los que recorren las democracias actuales. Solo un mal-

30. Mouffe, Ch. La paradoja democrática, op. cit., p. 30.

31. Ibíd., p. 46.

32. Ibíd., p. 37.

33. Ibíd., p. 113.

34. Ibíd., p. 48. 
entendido sorprendente puede llevarnos a creer que el liberalismo político presupone (ingenuamente) o aspira a imponer (autoritariamente) un consenso de fondo en torno a valores y orientaciones éticas que todos los grupos sociales deberían acatar de manera unánime. Si esta imagen de una sociedad culturalmente compacta subyace en alguna concepción de la democracia, no es desde luego en el liberalismo político, sino más bien en el modelo iliberal y proto-totalitario que podemos encontrar en El contrato social rousseauniano: un modelo en el que no es necesario buscar compromisos entre doctrinas comprehensivas diversas porque la diversidad no existe, siempre que los ciudadanos juzguen en conciencia los asuntos de interés general sin dejarse confundir, enredar 0 contaminar por los intereses (por principio espurios, en tanto que opuestos al interés general) de facciones, partidos o camarillas. ${ }^{35}$ Para Rousseau -y sobre todo, poco después, para Robespierre y el Comité de Salud Pública- el disenso individual y las diferencias políticas solo pueden interpretarse como indicios de corrupción moral, y por eso en una República "bien ordenada" en el sentido rousseauniano o jacobinototalitario, pero desde luego no en el sentido rawlsiano o liberal, no hay lugar para la libertad de expresión y de discusión en la

35. Rousseau, J.-J. (1988/1762). El contrato social, Madrid, Tecnos, Libro II, cap. 3. Un evaluador de la revista señala que la lectura de Rousseau que sugerimos aquí es muy sesgada y ha sido ya ampliamente criticada. Si bien esta lectura de Rousseau está respaldada en muchos pensadores liberales del siglo XX, lo cierto es que Rousseau no es Robespierre, y hacer justicia a su contractualismo nos obligaría a distinguirlo de la interpretación que le dieron los jacobinos (o el propio Carl Schmitt). No obstante, esas precisiones rebasarían ampliamente el marco argumentativo y la extensión disponible para este artículo. esfera pública, ni para las elecciones libres, los partidos políticos o el derecho a disentir, ni en general para ninguna otra expresión de ese pluralismo político que los teóricos agonísticos encarecen constantemente como la gran alternativa a la democracia liberal, cuando en realidad es la sustancia misma de la democracia liberal.

Esta lectura manifiestamente errónea, que parece confundir la democracia liberal de Rawls con la democracia totalitaria de Rousseau o Robespierre, se completa con una apropiación no menos sorprendente de un autor tan escurridizo como Carl Schmitt, cuya concepción iliberal de la política se invoca para profundizar o radicalizar la democracia liberal. ${ }^{36} \mathrm{La}$ ambigüedad del célebre ensayo de Schmitt sobre El concepto de lo político es muy oportuna a estos efectos. Es sabido que Schmitt define "lo político" mediante la contraposición de amigo y enemigo, y que propone esta definición como la alternativa correcta a las categorías de un liberalismo político que omite en la teoría y proscribe en la práctica el verdadero antagonismo y prioriza los recursos del acuerdo, la negociación y el compromiso. ${ }^{37}$ Lo que el liberalismo no entiende, según Schmitt, es que la verdadera política o la política auténtica (y no corrupta o degradada) solo aflora en aquellos antagonismos que no admiten acuerdos ni compromisos porque cada una de las partes implica para las otras la "negación del propio modo de existencia", es decir, una amenaza. ${ }^{38}$ Esta "negación" es una

36. Cf. sobre esto López de Lizaga, J. L. (2012). "Diálogo y conflicto. La crítica de Carl Schmitt al liberalismo", Diánoia, volumen LVII, número $68,113-140$.

37. Cf. Schmitt, C. (1998/1932). El concepto de lo político, Madrid, Alianza, p. 58, pp. 97 y sigs.

38. Ibíd., p. 57. 
expresión demasiado abstracta e imprecisa para reconocer en ella la posibilidad de la represión o la violencia física contra los enemigos políticos, aunque Schmitt es algunas veces bastante explícito al respecto. ${ }^{39}$ Chantal Mouffe saca partido de esa ambigüedad de Schmitt. También para ella el antagonismo político auténtico es el que no admite acuerdos ni compromisos, en contra de lo que sostiene un liberalismo al que acusa alternativamente (no sin cierta inconsistencia) de ingenuo y de represivo. Pero como ningún partidario del modelo agonístico defenderá hoy la conveniencia de concretar el antagonismo político en la censura, la represión, la persecución o el exterminio de los adversarios, la radicalización agonística de la democracia solo podrá encomendarse a Carl Schmitt a condición de que el lenguaje schmittiano no se tome literalmente ni se reivindique muy en serio. El aggiornamento de Carl Schmitt en manos de Chantal Mouffe cumple perfectamente este objetivo. Para hacer compatible el pensamiento schmittiano con los principios de la democracia liberal (y por tanto con el liberalismo político), Mouffe propone reformular la idea de antagonismo por la de agonismo, y propone reinterpretar el enfrentamiento potencialmente mortal entre amigos y enemigos como una oposición entre adversarios,

(...) término este -añade Mouffe- que se define de modo paradójico como "enemigos amistosos", esto es, como personas que son amigas porque comparten un espacio simbólico común, pero que también son enemigas porque quieren organizar este espacio simbólico común de un modo diferente..$^{40}$

39. Ibíd., p. 63: "Los conceptos de amigo, enemigo y lucha adquieren su sentido real por el hecho de que están y se mantienen en conexión con la posibilidad real de matar físicamente."

40. Mouffe, Ch. La paradoja democrática, op. cit., p. 30. Cf. también p. 70 y pp. 114-115.
Se diría, pues, que tras un largo rodeo la democracia agonística termina conduciendo al punto de partida, es decir: al liberalismo político. Si la "negación del modo de existencia" del otro, de quien no piensa o no vive como nosotros, no ha de concretarse en la represión de sus ideas o en la persecución y la violencia física, entonces este agonismo entre adversarios (en tanto que contrapuesto al antagonismo entre enemigos) solo puede significar más o menos esto: que en las sociedades democráticas, como consecuencia de la libertad de pensamiento (o como dice Rawls, del "ejercicio de la razón en condiciones de libertad"), ${ }^{41}$ siempre existirán concepciones del mundo e ideologías políticas contradictorias y mutuamente excluyentes, y que los partidarios de cada una de ellas tendrán que aprender a convivir con los partidarios de las otras como mejor puedan, sobre la base de un conjunto de principios políticos comunes, aunque se opongan, se enfrenten o incluso se desprecien entre sí. Es decir, que a fin de cuentas la concepción agonística de la democracia de Mouffe viene a decir exactamente lo mismo que ya decía el liberalismo político de Rawls, y el recurso a un Carl Schmitt cuyo potencial fascista ha quedado convenientemente desactivado solo parece servir para reformular el liberalismo político en un lenguaje un poco más vistoso o un poco más emocionante. ${ }^{42}$

41. Rawls, J. El liberalismo politico, op. cit., p. 20.

42. El propio Rawls replica a las objeciones de los teóricos agonísticos en términos similares a lo que hemos expuesto en estas páginas. Así, por ejemplo, en su ensayo "Una revisión de la idea de razón pública”, op. cit., p. 166, n. 5, afirma lo siguiente: "Encuentro difícil distinguir su punto de vista de una forma de liberalismo político y de razón pública”. Y en la p. 167: “(...) Siempre hay varias formas permisibles de razón pública. Más aún, de vez en cuando se proponen nuevas 
Todas estas confusiones probablemente arraigan en lo que cabe considerar un error categorial en el pensamiento de Chantal Mouffe. Ya hemos mencionado que la reivindicación de un modelo agonístico de democracia se dirigía en su origen contra cierto consenso neoliberal asumido en los años noventa del siglo XX por los partidos políticos liberal-conservadores y socialdemócratas (o socialliberales, como probablemente sería más adecuado llamarlos a partir de entonces). Nada que objetar a esa crítica de la hegemonía neoliberal, ni a la crítica de la situación post-democrática que el neoliberalismo ha provocado. Pero el error categorial consiste en pensar que, para atacar una determinada orientación política hegemónica en las democracias liberales actuales, necesitamos atacar también (o fingir que atacamos, o coquetear con la idea de que atacamos) el propio marco normativo de la democracia liberal. Aunque insufle un interesante hálito de romanticismo en la actualidad política o describa como revolución permanente la confrontación política rutinaria en las democracias liberales, la exaltación del agonismo no logra provocar un nivel de conflicto político que rebase el marco normativo del liberalismo. $Y$ es una suerte que no lo logre, porque conviene no olvidar lo que significaría rebasar ese marco: significaría alcanzar un nivel de conflicto en el que las partes dejasen de reconocerse como iguales en derechos, dejasen de concebir la sociedad como un "esquema de cooperación" que todos tienen que poder considerar legítimo, y renunciasen a justificar sus posiciones en nombre de los derechos humanos.

variaciones y las antiguas dejan de estar representadas", por lo que "la crítica [de los teóricos agonísticos] por no permitir nuevas y cambiantes concepciones de la justicia política es, por tanto, incorrecta." (p. 167, n. 7).
Pero quizás ha comenzado ahora la fractura del liberalismo político que los teóricos agonísticos llevan años proponiendo o proclamando. Como los cambios sociales y políticos y sus correspondientes reflejos teóricos siempre son graduales, sería posible rastrear la historia que conduce paso a paso del liberalismo político a la teoría agonística y de ahí, imperceptiblemente, a la emergencia de una verdadera grieta en el marco normativo y en las formas de confrontación política de las democracias actuales. Una grieta que quizás se ha formado debido a cierta "fatiga de materiales" como la que afecta a veces a las construcciones y los edificios: a fuerza de tensar los conflictos y de desplazar el terreno de la confrontación política del disenso al agonismo, quienes antes eran adversarios han comenzado a considerarse unos a otros como auténticos enemigos schmittianos, ahora ya no en un sentido retórico pero políticamente inocuo, sino en el amenazador sentido que tuvo esta categoría alguna vez. Por eso observamos hoy ciertos indicios de un crudo conflicto político hasta ahora inédito, aunque algunos lo invocaran con impaciencia porque la política pacificada de las democracias liberales les parecía en general muy aburrida. Por el momento esto no parece conducir a estas sociedades hacia una saludable radicalización democrática, sino más bien al desprecio del adversario político, la normalización de la agresión verbal, la degradación del nivel argumentativo de la deliberación política, el lento retorno de la violencia física o el fenómeno en el que nos centraremos nosotros: la expansión del cinismo político. ${ }^{43}$

43. Emparentado con el cinismo político tenemos el fenómeno de la charlatanería, que el filósofo norteamericano Harry Frankfurt analizó en un ensayo visionario y completamente certero publicado en 1986. Cf. Frankfurt, H. (2013/1986). Sobre la charlatanería, Barcelona, Paidós. Cf. también 


\section{Cinismo político}

El cinismo representa una incógnita para el liberalismo político, una anomalía en el plano teórico que corresponde a la brecha que parece estar abriéndose en la vida política de las democracias liberales. No obstante, los escritos de Rawls aportan algunas pistas muy valiosas para avanzar en la comprensión de este fenómeno. Intentaremos a continuación rastrear esas pistas, pero lo haremos completando las ideas rawlsianas con la teoría del cinismo más interesante del pensamiento contemporáneo, propuesta por el filósofo alemán Peter Sloterdijk. ${ }^{44}$ La combinación de ambos autores nos permitirá analizar tres rasgos básicos del cinismo político: (1) al igual que el fanatismo, el cinismo es incompatible con el liberalismo político, pero en cierto sentido el cinismo es

López de Lizaga, J. L. (2020). “Charlatanería y cinismo", XV Boletín de estudios de filosofía y cultura Manuel Mindán, 75-85. Para analizar el cinismo, del cual nos ocuparemos en lo que sigue, disponemos de una teoría más completa, desarrollada por el filósofo alemán Peter Sloterdijk especialmente en su Crítica de la razón cínica (1983). La realidad confirma hoy estos análisis, que nos dicen mucho sobre la actual crisis del liberalismo político aunque fueron formulados originalmente en la década de 1980, como si en las sociedades modernas existiera desde hace décadas el germen de inquietantes posibilidades políticas que solo ahora comienzan a realizarse plenamente o a mostrarse de manera descarada.

44. Para nuestra argumentación nos atendremos a algunas ideas de Peter Sloterdijk. No obstante, un estudio completo de la rehabilitación de la filosofía cínica en el pensamiento contemporáneo debería contemplar a otros autores, como Michel Foucault o Michel Onfray. Sobre la rehabilitación del cinismo antiguo en la filosofía contemporánea, cf. Baquero Gotor, A. (2020). La traición a Diógenes. Lecturas contemporáneas de la filosofía cínica, Zaragoza, PUZ. la antítesis del fanatismo; (2) el cinismo está relacionado con una concepción enteramente estratégica de la racionalidad, y surge cuando se renuncia a la argumentación racional en la esfera pública; y (3) el cinismo amenaza seriamente la democracia liberal porque erosiona la concepción de la sociedad como un "esquema equitativo de cooperación", dicho en términos rawlsianos.

[1] El conflicto agonístico puede poner a prueba la resistencia del liberalismo político, pero el cinismo impacta en su arquitectura como un proyectil y provoca una desestabilización mucho mayor, porque anula la posibilidad de un "desacuerdo razonable". Ya hemos visto que, según Rawls, es razonable el desacuerdo entre ideas, ideologías o doctrinas comprehensivas que no se afirman dogmáticamente, ni pretenden imponerse por la fuerza, ni ven en las ideas, ideologías o doctrinas rivales una schmittiana amenaza del propio modo de existencia (una amenaza que habría que erradicar en un sentido simbólico, pero eventualmente también en sentido físico). Vimos también cómo, a consecuencia de todo lo anterior, el paradigma de lo irrazonable y el verdadero antagonista del liberalismo político es el dogmático, el fanático, el fundamentalista. Ahora bien, lo cierto es que la dicotomía entre demócratas razonables y fanáticos irrazonables no agota todas las posibles actitudes epistémicas hacia nuestras creencias o convicciones políticas. En concreto, no permite captar en qué consiste el cinismo, que no es una actitud razonable pero tampoco dogmática, ni es propia de furiosos fanáticos, pero tampoco de verdaderos demócratas.

A diferencia de los ciudadanos razonables, los dogmáticos irrazonables son, 
según Rawls, quienes "imponen sus creencias porque, dicen, sus creencias son verdaderas, no porque sean suyas". ${ }^{45}$ Pues bien, basta con invertir los términos de esta frase para captar un primer rasgo esencial del cinismo, puesto que el cínico es, desde el punto de vista político, quien afirma sus creencias porque son suyas sin preocuparse en absoluto de si son o no son verdaderas, o para decirlo con más precisión: sin que le importe si esas creencias están bien o mal justificadas, o si son aceptables o no por aquellos a los que conciernen o afectan. $Y$ siguiendo esta pista rawlsiana podemos precisar cuál es la grieta que el cinismo abre en la democracia liberal. Su irrupción introduce en la esfera pública una forma de antagonismo que invalida la principal condición de posibilidad del "pluralismo razonable" $y$, por tanto, de la convivencia entre diferentes formas de pensar y vivir: se trata del requisito de argumentar las propias posiciones políticas en los términos de la razón pública, es decir, basándose en recursos conceptuales y normativos que las otras partes puedan aceptar, incluso si no comparten la posición que uno defiende. Es evidente que los dogmáticos o los fanáticos desprecian la idea de una razón pública y no aceptan este requisito. Conciben la sociedad como un "orden natural fijo"46 que ellos conocen y que están dispuestos a imponer sin atender a las concepciones y razones de otros, y lo hacen convencidos de que su doctrina, y solo la suya, es verdadera. El cinismo es otra cosa. También el cínico se desentiende de la exigencia de argumentar sus posiciones, de justificarlas razonablemente ante otros, y también él se limita a imponerlas si tiene el poder para hacerlo. Pero

45. Rawls, J., El liberalismo político, op. cit., p. 92. 46. Ibíd., p. 45. a diferencia del dogmático o del fanático, el cínico no se desentiende de ese compromiso con la razón pública porque se considere en posesión de la verdad, sino que, más bien al contrario, al cínico no le importa si su posición es verdadera, o es correcta, o es justa, o está justificada. En este sentido representa la inversión exacta de la definición del fanático que propone Rawls. El fanático impone sus creencias porque (dice) son verdaderas, el cínico las impone porque son suyas. El fanático es Bossuet, el cínico es Trump.

[2] Peter Sloterdijk fue el primero en captar la importancia filosófica y política del nuevo cinismo, al cual dedicó un libro extraño y un poco cínico a su vez: la Crítica de la razón cínica, publicada en 1983. Según Sloterdijk, la principal característica de la cultura cínica -en la que las sociedades occidentales se habrían adentrado desde finales del siglo pasado- es la renuncia a las pretensiones de validez o de justificación racional. Su análisis enlaza, si bien de un modo muy peculiar, con la Teoría Crítica frankfurtiana. La Crítica de la razón cínica se presenta a sí misma como "una meditación sobre la máxima "saber es poder»"47, que ocupó intensamente a los autores de la Dialéctica de la Ilustración: si es cierto -como sostuvieron los autores frankfurtianos siguiendo a Max Weber- que la racionalidad está esencialmente relacionada con el dominio, entonces la consumación del racionalismo occidental corresponderá a una cultura que ha quedado vaciada de toda pretensión de validez, y en la que "todo pensamiento se ha hecho estrategia." 48 Y también en la línea de Dialéctica de la Ilustración, la Crítica de la razón cínica presenta una

47. Sloterdijk, P. (1989/1983). Crítica de la razón cínica, Madrid, Taurus, vol. 1, p. 12.

48. Ibíd., p. 14. 
genealogía del cinismo contemporáneo a partir de su antítesis, el ideal ilustrado de una sociedad integrada a través de la Razón o, en un lenguaje más actual, a través de la aceptación libre y unánime de los mejores argumentos. De acuerdo con la imagen que tienen de sí mismos, los ilustrados (del siglo XVIII o del XXI) son quienes no combaten, sino que argumentan; quienes no fuerzan, sino que convencen. La llustración aspira a que "la conciencia contraria no se retire de su actual posición más que bajo la presión del argumento convincente" ${ }^{49}$ Pero esta "saludable ficción"50 del poder de las razones en un diálogo libre se derrumba tan pronto como los participantes en el debate público constatan que sus argumentos, aunque sean buenos, no son suficientes para imponerse a los argumentos de la parte contraria, aunque sean peores. La llustración recibe una severa derrota cuando, a pesar de la contundencia de los razonamientos, los aristócratas dieciochescos no ceden un ápice de su poder político a los burgueses del tercer estado, ni los burgueses ceden una parte de sus beneficios al proletariado, ni el proletariado admite sin resistencias las consignas del Partido que le informa acerca de sus intereses objetivos, ni los terraplanistas abrazan el copernicanismo, ni los creyentes abjuran de su fe, ni los carnívoros se hacen veganos.

Como ya sabemos, hay un ramal del pensamiento ilustrado que conduce al liberalismo político de Rawls aceptando que estas diferencias (o algunas de ellas) son consecuencias inevitables de las "cargas del juicio" y de la libertad de pensamiento. Pero hay otra línea de la llustración que

49. Ibíd., p. 41.

50. Ibíd., p. 43. es la que interesa a Sloterdijk, y que ante la falta de acuerdo adopta un nuevo enfoque metodológico en las controversias políticas: la crítica de la ideología, o "la continuación polémica con otros medios del diálogo fracasado". ${ }^{51}$ Ante la impotencia de los argumentos, ante la asombrosa "sordera del contrario", 52 cada una de las partes comienza ahora a cuestionar no solo las ideas de la parte contraria, sino los motivos que tiene para defenderlas. Quien no atiende a razones solo puede sostener lo que sostiene por "equivocación o voluntad perversa", 53 es decir: por ignorancia (o alienación) o por maldad. Las partes dejan de reconocerse mutuamente como adversarios y empiezan a verse más bien como enemigos o incluso como objetos, puesto que la crítica de la ideología ya no toma en serio la libertad de conciencia del adversario (ahora reducida a "falsa conciencia") ni se toma ya la molestia de intentar comprender sus razones, sino que a lo sumo buscará una explicación del mecanismo que conduce a alguien a seguir defendiendo ideas que parecen manifiestamente falsas. La crítica de la ideología reemplaza de este modo la intersubjetividad del diálogo libre por la inter-objetivación del desenmascaramiento mutuo.

El declive del liberalismo político comienza aquí. La crítica de la ideología hace imposible el entendimiento de los adversarios, puesto que no permite que sus posiciones se acerquen un solo paso: "en la crítica de la ideología ya no se trata de atraer al propio bando al enemigo viviseccionado; el interés se centra en su cadáver" ${ }^{54}$ Pero

51. Ibíd., p. 45.

52. Ibíd., p. 43.

53. Ibíd., p. 45.

54. Ibíd., p. 47.

Revista Internacional de Pensamiento Político - I Época - Vol. 16 - 2021 - [517-536] - ISSN 1885-589X 
tampoco admite que el desacuerdo entre ellos sea razonable, puesto que la parte contraria tiene que estar alienada o argumentar de mala fe. Entre antagonistas que se acusan mutuamente de alienación o de bajeza moral ya solo es posible el desprecio, que por otra parte permite a todos sobrellevar la frustración de no haber logrado convencer a la parte contraria: "solo así, por medio de un permanente desprecio, los ideólogos logran de alguna manera vivir con la pluralidad de las ideologías". ${ }^{55}$ No obstante, conviene advertir que la crítica de la ideología no se ha desprendido aún de toda referencia a la verdad o a la justificación racional de las opiniones. Se deniega al otro toda pretensión de validez, pero se reclama todavía como propia. El otro está alienado, pero no nosotros; el otro miente, pero nosotros no. Por eso es más inquietante el siguiente paso hacia el cinismo, que empieza a esbozarse en nuestra propia época y que se da cuando las partes no solo niegan a los demás la pretensión de racionalidad de sus opiniones, sino que por su parte renuncian también a ella. Lo que unos y otros defienden parece ser simplemente lo que prefieren o desean o les conviene defender. Y así, en la sociedad en la que se generaliza la crítica ideológica y las acusaciones de falsa conciencia vuelan en todas direcciones, la única justificación de las ideas (propias o ajenas) parece ser el crudo voluntarismo de los intereses. Para consumar el paso al cinismo basta con que las partes interioricen el descrédito generalizado de las pretensiones de validez; basta con que cada una renuncie a justificar ante otros sus puntos de vista, y se limite a esgrimir para defenderlos eso que de todos modos todos consideran como el único argumento disponible: que

55. Ibíd., p. 49. las ideas de cada parte son simplemente las que cada parte necesita para apuntalar sus propios intereses, o que cada cual sostiene su verdad no porque sea verdad, sino porque es la suya. Solo entonces se generaliza en la vida social la máxima "saber es poder", y la sociedad se vuelve completamente cínica.

[3] El liberalismo político rawlsiano se preguntaba cuáles pueden ser los principios de una razón pública que aporten el marco común en el que puedan confrontarse y dirimirse las diferencias políticas razonables. La respuesta de Sloterdijk a esta pregunta sería que, en una época cínica, lo único que tienen en común los diferentes puntos de vista es su nuda pretensión de poder, lo cual es tanto como afirmar que la era del cinismo político es aquella en la que se debilita la noción misma de un marco político común o la idea de comunidad. El cínico es quien, precisamente, ya no comparte ningún espacio con el adversario, y por eso ya no se siente obligado a justificar sus posiciones en términos que el adversario pueda aceptar aunque no haya acuerdo entre ambos. Dicho en términos rawlsianos: el cínico ha renunciado a ver la sociedad como un "esquema equitativo de cooperación". No quiere saber nada de una razón pública común, ni siquiera de un mundo social común, y tampoco quiere tener que justificar su indiferencia hacia todo ello. El cinismo es, pues, la conciencia política propia de una sociedad atomizada y agonística, una sociedad de individuos aislados y de grupos sociales encapsulados que se rigen únicamente por su propia conveniencia e interactúan de un modo enteramente estratégico, es decir: orientado a la neutralización del adversario, cada vez más asimilado a la categoría schmittiana de enemigo. El liberalismo político se derrumba cuando se 
esfuma de la conciencia de todos la obligación cívica de justificar razonablemente ante el adversario el punto de vista propio. Renunciar a la pretensión de racionalidad y seguir juzgando igual, con razones o sin ellas. Afirmar sin pestañear lo que no se sostiene y "actuar contra mejor saber". ${ }^{56}$ Estas son las cualidades de una época políticamente cínica, como empieza a ser la nuestra.

Tenemos ejemplos de ello en la actualidad política diaria. Inolvidable, pionero y absolutamente cínico fue el famoso exabrupto "ique se jodan!", proferido en 2012 por una diputada conservadora en el Parlamento español cuando se anunciaba el recorte de las ayudas a los parados en un contexto de severa crisis económica. ${ }^{57} \mathrm{Al}$ gunos años después, la Presidenta de la Comunidad de Madrid y correligionaria de aquella diputada insultaba públicamente a las personas que acuden a los comedores sociales refiriéndose a ellas como "mantenidos subvencionados." ${ }^{8} \mathrm{Y}$ si ampliamos el foco, hallaremos ejemplos de este descarado cinismo político en otros

\section{Ibíd.}

57. https://www.lavanguardia.com/politica/20120713/54324975022/andrea-fabra-quese-jodan.html

Por otra parte, esta diputada quizás se inspiraba en una tradición de cinismo familiar, puesto que era hija de un presidente autonómico que, tras hacer construir un aeropuerto totalmente innecesario en su Comunidad Autónoma, justificó públicamente aquel dispendio de fondos públicos argumentando con perfecto cinismo que se trataba de un aeropuerto construido "para las personas", en lugar de para los inexistentes aviones, viajeros o compañías aéreas que normalmente deberían beneficiarse de una instalación de ese tipo. Cf. https://www.publico.es/espana/fabrainaugura-castellon-aeropuerto-aviones.html

58. https://www.publico.es/politica/ayuso-llamamantenidos-subvencionados-acuden.html países. Noam Chomsky se sorprendía en una entrevista de 2016 por la impunidad de las mentiras durante la campaña que llevó al poder a Donald Trump: lo novedoso políticamente no es la mentira, pero sí el cinismo y la impunidad con que se miente. ${ }^{59}$ La periodista Anne Applebaum aprecia en los intelectuales húngaros rendidos al poder de Orbán una inquietante capacidad de "convencerse provechosamente a sí mismos de creer aquello que resulta ventajoso creer"60, frase ésta que bien podría servir como una definición del cinismo. En un ensayo brillante, Bruno Latour destaca la centralidad de la mentira (y en concreto, del negacionismo en relación con el cambio climático) en el proyecto político de las élites de los países desarrollados: es imprescindible negar contra toda evidencia la crisis medioambiental si lo que se pretende es desarrollar una política ecológicamente irresponsable que, sin embargo, asegure el mantenimiento del nivel de vida de las sociedades desarrolladas durante las pocas décadas que les queden de vida a las actuales generaciones de votantes (cuyo comportamiento electoral, dicho sea de paso, ha de considerarse tan cínico como el de las élites políticas a las que apoyan). ${ }^{61} \mathrm{Y}$ por último, el éxito e incluso la sorprendente respetabilidad filosófica del extraño y eufemístico concepto de "post-verdad" es también muy sintomático de una época en la que virtualmente cualquier cosa puede defenderse sin argumentos, y en la

59. "Me sorprendió la irrelevancia de los hechos. Ya no importan cuáles son ciertos y cuáles son falsos. La verdad es irrelevante." Chomsky, N. et al. Neofascismo: De Trump a la extrema derecha europea, op. cit., p. 89.

60. Applebaum, A. (2021). El ocaso de la democracia, Barcelona, Debate, p. 56.

61. Latour, B. (2017). "La Europa refugio", en VVAA, El gran retroceso, Barcelona, Seix Barral. 
que consecuente e inevitablemente proliferarán como una plaga los charlatanes, los mentirosos, los negacionistas, los irresponsables, los oportunistas y los cínicos. ${ }^{62}$

\section{Conclusión}

El cinismo político no es una ideología, sino un estilo discursivo, una forma de comunicación en la esfera pública. De ahí se sigue que, en principio, el cinismo puede ponerse al servicio de cualquier ideología: cabe imaginar un cinismo de izquierdas o de derechas, revolucionario o reaccionario, etc. No obstante, los ejemplos mencionados más arriba indican con bastante claridad cuál es hoy la orientación política que se sirve del estilo cínico, o que lo fomenta. Cuando Sloterdijk publicó su premonitorio análisis, el cinismo era solo incipiente y podía contemplarse con cierto optimismo, como una saludable reacción a la seriedad de años anteriores: si estaban ya un poco hastiados del clima opresivo de la Guerra Fría o de la gravedad crítica de los filósofos frankfurtianos, los lectores alemanes de Sloterdijk podían reconocer en la Crítica de la razón cínica la celebración de cierto individualismo un poco frívolo y políticamente despreocupado, muy característico de los años ochenta. "Contra el principio esperanza surge el principio de vivir aquí y ahora", ${ }^{63}$ escribía

62. Sobre el concepto de post-verdad, cf. McIntyre, L. (2018). Posverdad, Madrid, Cátedra; y D'Ancona, M. (2019). Posverdad, Madrid, Alianza.

63. Sloterdijk, P. Crítica de la razón cínica, op. cit., p. 144. Cf. también p. 132: "Al disolverse la base sobre la que se asienta la Ilustración (...) se hacen borrosas las perspectivas de aquello que anteriormente se llamaba compromiso. Si alguien quiere empezar a "agitarme" ilustradamente, lo primero que se me ocurre es efectivamente
Sloterdijk. En aquel contexto esta filosofía podía resultar menos corrosiva de lo que nos resultaría hoy, porque el libro de Sloterdijk se burlaba de todo, pero mirándolo todo desde abajo, es decir, desde una posición políticamente indefinida pero que en ningún caso parecía coincidir con la de las clases dominantes. Este posicionamiento político de Sloterdijk tenía incluso un reflejo terminológico: aunque según él las actitudes cínicas no entendían de clases sociales y podían reconocerse en "empresarios sin escrúpulos y pasotas desilusionados"64 (es decir, tanto en las élites como en los marginados), Sloterdijk se esforzaba por distinguir un cinismo señorial de un "quinismo" plebeyo. ${ }^{65} \mathrm{La}$ diferencia es importante. El cinismo es la actitud de quien ha renunciado a la pretensión de verdad o de justificación racional pero sigue afirmando sus posiciones porque le conviene hacerlo, es decir, de un modo enteramente instrumental o estratégico, y siempre con el objetivo de imponer sus propios intereses contra otros. El "quínico", en cambio, también piensa que nada es verdadero ni puede justificarse racionalmente, pero airea abiertamente esta generalizada falta de fundamentos y desacata toda autoridad supuestamente fundada en la racionalidad o en la verdad. El cinismo, representado por figuras literarias como el Mefistófeles de Goethe o el Gran Inquisidor de Dostoyevsky, tiende a ponerse del lado del poder y a despreciar a quienes ocupan una posición social inferior, y por eso tiene siempre un punto

un cinismo: el interesado debe preocuparse primeramente de su propia mierda".

64. Sloterdijk, P. Crítica de la razón cínica, op. cit., p. 33.

65. Sobre esta distinción, cf. Baquero Gotor, A. (2020). La traición a Diógenes. Lecturas contemporáneas de la filosofía cínica, op. cit., p. 136 ss. 
de crueldad potencialmente fascista: "el señor cínico alza ligeramente la máscara, sonríe a su débil contrincante y le oprime. C'est la vie."66 En cambio, el quinismo tiene un carácter plebeyo y más amable, porque se burla sobre todo de las jerarquías, tal como hacía Diógenes en la Antigüedad o, en nuestros días, el propio Sloterdijk, cuyo libro no solo teorizaba, sino que también reivindicaba y ejercía esa irreverencia potencialmente subversiva. ${ }^{67}$

Pero en un ensayo más reciente, publicado en 2018, y en el que en cierto modo pone al día su teoría, Sloterdijk admite que el cinismo actual es más inquietante que el de la década de 1980, puesto que ahora el "quínico" arquetípico ya no es el "pasota desilusionado", el individualista que se desentiende del mundo común o de las preocupaciones colectivas desde una posición marginal. Más bien sucede que el quinismo plebeyo se torna hoy cada vez más indiscernible del cinismo señorial, y ahora es común a élites y masas una cínica "dispensa autoconcedida de satisfacer las imposiciones excesivas de una moral universal"68. Dicho de otro modo: hoy como ayer, el cinismo se desentiende de lo común (del mundo común, de las preocupaciones colectivas), pero ya no lo hace dando la espalda al bien común -

66. Ibíd., p. 159.

67. No todo el mundo ha visto en Sloterdijk una posición política tan amable. En una demoledor análisis de la propuesta de Sloterdijk de una "fiscalidad voluntaria", Axel Honneth desenmascara al escurridizo filósofo del quinismo como un turbio ideólogo del peor neoliberalismo. Al final, el quínico Sloterdijk no sería nada más que un cínico. Cf. Honneth, A. (2011). "Fatales profundidades desde Karlsruhe. Peter Sloterdijk y su propuesta de una fiscalidad voluntaria", Revista de Occidente, número 361, 77-89.

68. Sloterdijk, P. (2020). Las epidemias políticas, Ediciones Godot. Edición de Kindle, p. 13. como sería propio del quínico marginal-, sino más bien afirmándose abiertamente contra éste. ${ }^{69}$ El quinismo plebeyo parece haberse diluido en un cinismo señorial que, sorprendentemente, se difunde en todos los estratos sociales: ya no quedan quínicos, sino que solo hay cínicos, sea cual sea la posición social que ocupen. Por eso la era del cinismo consumado es el tiempo en que las masas premian e imitan el cinismo señorial de los "empresarios sin escrúpulos", pese a ser ellas sus primeras víctimas; y por eso empezamos a observar, quizás por primera vez desde la derrota del fascismo, cómo incluso los gobernantes se permiten frivolizar impunemente con el bien común o despreciar abiertamente los requisitos de la equidad y la razonabilidad, exactamente como si fueran personajes marginales o "pasotas desilusionados". Si, como a veces se dice, cierto neofascismo merodea hoy en torno a nuestras democracias, el cinismo político será una de las llaves que le permitan irrumpir en ellas.

\section{Bibliografía}

APPLEBAUM, A. (2021). El ocaso de la democracia, Barcelona, Debate.

BAQUERO GOTOR, A. (2020). La traición a Diógenes. Lecturas contemporáneas de la filosofía cínica, Zaragoza, PUZ.

69. Las élites ya no ocultan "su indiferencia ante la preocupación por el bien común que se les asigna oficialmente." Sloterdijk cita a Warren Buffett como ejemplo de este descarado cinismo señorial: "En nuestros días, Warren Buffet pertenece a aquellos grupos bien altos, que a veces consideran que ya no necesitan una máscara: «Hay una guerra de clases, de acuerdo, pero es la mía, la de los ricos, la que está haciendo esa guerra, y vamos ganando»". Sloterdijk, P. Las epidemias politicas, op. cit., p. 12-13. 
CASTELLS, M. (2020). Ruptura. La crisis de la democracia liberal, Madrid, Alianza. CHOMSKY, N. et al. (2017). Neofascismo: De Trump a la extrema derecha europea, Capital Intelectual. Edición de Kindle.

CROUCH, C. (2004). Posdemocracia, Madrid, Taurus.

D'ANCONA, M. (2019). Posverdad, Madrid, Alianza.

FRANKFURT, H. (2013/1986). Sobre la charlatanería, Barcelona, Paidós.

HABERMAS, J. (1990/1962). Strukturwandel der Öffentlichkeit, Frankfurt a.M., Suhrkamp.

HONNETH, A. (2011). "Fatales profundidades desde Karlsruhe. Peter Sloterdijk y su propuesta de una fiscalidad voluntaria", Revista de Occidente, número 361, 77-89.

KOSELLECK, R. (1973/1959). Kritik und Krise, Frankfurt a.M., Suhrkamp.

LATOUR, B. (2017). "La Europa refugio", en VVAA, El gran retroceso, Barcelona, Seix Barral.

LÓPEZ DE LIZAGA, J. L. (2011). "Verdades religiosas, política laica: Habermas sobre la religión en la esfera pública", en J. Franzé y J. Abellán (eds.), Política y Verdad, Madrid, Plaza y Valdés, 175-208.

LÓPEZ DE LIZAGA, J. L. (2012). “¿Razón o revolución? El republicanismo de Kant y Georg Forster", Foro Interno, vol. 12, 81106.

LÓPEZ DE LIZAGA, J. L. (2012). "Diálogo y conflicto. La crítica de Carl Schmitt al liberalismo", Diánoia, volumen LVII, número 68, 113-140.

LÓPEZ DE LIZAGA, J. L. (2019). "El entusiasmo de la Revolución. Sobre la filiación kantiana del último Foucault", Ágora, vol. $38, n^{\circ} 1,165-181$.

LÓPEZ DE LIZAGA, J. L. (2020). "Charlatanería y cinismo", XV Boletín de estudios de filosofía y cultura Manuel Mindán, 7585.

MCINTYRE, L. (2018). Posverdad, Madrid, Cátedra.

MOUFFE, Ch. (2012). La paradoja democrática, Barcelona, Paidós.

RAWLS, J. (2001/1999). "Una revisión de la idea de razón pública", en El derecho de gentes, Barcelona, Paidós.

RAWLS, J. (2003/1993). El liberalismo político, Barcelona, Crítica.

ROUSSEAU, J.-J. (1988/1762). El contrato social, Madrid, Tecnos.

SCHMITT, C. (1998/1932). El concepto de lo político, Madrid, Alianza.

SCHMITT, C. (2002/1923). Sobre el parlamentarismo, Madrid, Tecnos.

SLOTERDIJK, P. (1989/1983). Crítica de la razón cínica, 2 vols., Madrid, Taurus.

SLOTERDIJK, P. (2020). Las epidemias políticas, Ediciones Godot. Edición de Kindle. 